\title{
What are the roles of global DNA and APC 2 gene promotor hypermethylation in multiple myeloma?
}

\author{
Sacide Pehlivan ${ }^{1} \cdot$ Istemi Serin $^{2}$ (D $\cdot$ Ayse Feyda Nursal ${ }^{3} \cdot$ Yasemin Oyaci $^{1} \cdot$ Ilknur Gundes ${ }^{4} \cdot$ Mustafa Pehlivan $^{2,5}$
}

Received: 21 August 2021 / Accepted: 5 October 2021 / Published online: 12 October 2021

(c) The Author(s), under exclusive licence to Springer Nature B.V. 2021

\begin{abstract}
Background In today's practice, gene-based approaches come to the fore in the determination of prognosis and treatment preferences of multiple myeloma (MM). DNA methylation is one of the new approach parameters. DNA methylation occurs by the addition of a methyl group to cytosines in $\mathrm{CpG}$ dinucleotides. In this study, besides comparing the global DNA and APC 2 gene promotor hypermethylation between our patients with MM and healthy control group, we aimed to demonstrate the effect of hypermethylation on MM treatment responses and survival.

Methods and results 38 patients diagnosed with MM between January 2016 and January 2020 and 50 healthy controls were included in the study. The initial hypermethylation of the patients and the healthy control group were statistically analyzed. In addition, the increase in hypermethylation in the MM group before and after the first series of treatments were analyzed within themselves. There is a significant difference between the patients with MM diagnosis and the healthy control group in terms of the initial global hypermethylation $(\mathrm{P}=0.001)$. In patients with $\mathrm{MM}$, hypermethylation was significantly higher. Global hypermethylation in the post-treatment measurements was significantly increased in comparison to the pre-treatment state $(\mathrm{P}=0.012)$. In terms of APC 2 promotor gene-specific hypermethylation, no significant differences were detected between pre- and post-treatment values $(\mathrm{P}=0.368)$.

Conclusions This study represents valuable data with the initial global DNA hypermethylation results in the MM patient group and the increase in hypermethylation post-treatment. it will shed light on future studies.
\end{abstract}

Keywords Multiple myeloma $\cdot$ DNA methylation $\cdot$ Treatment $\cdot$ Response $\cdot$ Survival

$\begin{array}{ll}\text { Abbreviations } \\ \text { MM } & \begin{array}{l}\text { Multiple myeloma } \\ \text { PET/CT }\end{array} \\ \begin{array}{ll}\text { Positron emission tomography/computed } \\ \text { tomography }\end{array} \\ \text { MR } & \text { Magnetic resonance } \\ \text { CT } & \text { Computed tomography }\end{array}$

Istemi Serin

serinistemi@hotmail.com

1 Department of Medical Biology, Faculty of Medicine, Istanbul University, Istanbul, Turkey

2 Department of Hematology, Istanbul Training and Research Hospital, University of Health Sciences, Org. Nafiz GURMAN Cad. 34098, Fatih, Istanbul, Turkey

3 Department of Medical Genetics, Faculty of Medicine, Hitit University, Çorum, Turkey

4 Department of Internal Medicine, Faculty of Medicine, Gaziantep University, Gaziantep, Turkey

5 Department of Hematology, Faculty of Medicine, Gaziantep University, Gaziantep, Turkey

$\begin{array}{ll}\text { SOCS-1 } & \text { Suppressor of cytokine signaling-1 } \\ \text { SHP-1 } & \begin{array}{l}\text { Src homology region 2 domain-containing } \\ \text { phosphatase-1 }\end{array} \\ \text { APC } & \text { Adenomatous polyposis coli } \\ \text { Wnt-1 } & \text { Wingless and Int-1 } \\ \text { OS } & \text { Overall survival } \\ \text { PFS } & \text { Progression-free survival } \\ \text { IPI } & \text { International Prognostic Index } \\ \text { ECOG } & \text { Eastern Cooperative Oncology Group } \\ \text { LDH } & \text { Lactate dehydrogenase } \\ \text { CRP } & \text { C-reactive protein } \\ \text { ASCT } & \text { Autologous stem cell transplantation } \\ \text { VCD } & \text { Bortezomib-cyclophosphamide and } \\ & \text { dexamethasone } \\ \text { LD } & \text { Lenalidomide-dexamethasone } \\ \text { 5mC } & \text { 5-Methylated cytosines } \% \\ \text { OD } & \text { Optical density } \\ \text { OR } & \text { Odd ratio } \\ \text { CLL } & \text { Chronic lymphocytic leukemia }\end{array}$




\begin{tabular}{|c|c|}
\hline MGUS & $\begin{array}{l}\text { Monoclonal gammopathy of undetermined } \\
\text { significance }\end{array}$ \\
\hline PCL & Plasma cell leukemia \\
\hline RBP1 & Retinol-binding protein 1 \\
\hline GPX3 & Glutathione peroxidase 3 \\
\hline SPARC & Secreted protein acidic and rich in cysteine \\
\hline TGFBI & Transforming growth factor beta-induced \\
\hline CYLD & Conserved cylindromatosis \\
\hline WIF1 & WNT inhibitory factor 1 \\
\hline DKK & Dickkopf-related protein \\
\hline BCL9 & B-cell CLL/lymphoma 9 \\
\hline sFRP & Soluble frizzled-related protein \\
\hline LGR4 & $\begin{array}{l}\text { Leucine-rich repeat-containing G-protein cou } \\
\text { pled receptor } 4\end{array}$ \\
\hline ALL & Acute lymphoblastic leukemia \\
\hline AML & Acute myeloid leukemia \\
\hline CYP1B1 & $\begin{array}{l}\text { Cytochrome p } 450 \text { family subfamily B } \\
\text { polypeptide }\end{array}$ \\
\hline
\end{tabular}

\section{Introduction}

Multiple myeloma (MM) constitutes approximately $10 \%$ of hematological malignancies. It is a disease caused by malignant plasma cells, the pathology of which is abnormal proliferation, causing free light-chain release accompanying the increase in monoclonal immunoglobulin [1]. It is possible to say that the data obtained from many publications are seen around 4-7/100,000 and the median age is 65 [2, 3]. Clinical manifestations appear as renal failure, anemia, hypercalcemia, lytic bone lesions. Although positron emission tomography/computed tomography (PET/CT) is often preferred for the detection of lytic bone lesions, magnetic resonance (MR), computed tomography (CT) and direct radiographs also contribute to the diagnosis [4].

In today's practice, gene-based approaches come to the fore in the determination of the prognosis and treatment preferences of MM. At this point, DNA methylation is one of the new approach parameters. DNA methylation occurs by the addition of a methyl group to cytosines in $\mathrm{CpG}$ dinucleotides. Abnormal DNA methylation in the $\mathrm{CpG}$ island has also been associated with the suppression of tumorsuppressor genes (inhibition of transcription) [5, 6]. In the normal genome, about $70 \%$ of the $\mathrm{CpG}$ dinucleotides are methylated. This process commonly occurs in CpGs located in the inter-genes and intron regions or gene main bodies and causes the production of alternative transcripts specific to cell type and function [6].

The hematopoietic cell capacity of the bone marrow is directly proportional to its self-renewal capacity. Hematopoiesis is formed by the differentiation of progenitors with limited self-renewal properties. The self-renewal and differentiation abilities of the stem cells and the balance formed in this process are controlled by epigenetic mechanisms. It must be noted that one of the changes occurring in this mechanism is DNA methylation of $\mathrm{CpG}$ dinucleotides. $\mathrm{CpG}$ islands are found in approximately $40 \%$ of mammalian promoters, particularly tumor-suppressor genes [7]. Hypermethylation, which involves the addition of a methyl group to the fifth position of the deoxycytidine residue in each $\mathrm{CpG}$ dinucleotide affected, results in remodeling of the chromatin structure. Silenced gene and inhibited tumor suppression mechanisms are also associated with carcinogenesis. Epigenetic modifications such as global DNA methylation are dynamic and reversible with proven therapeutic approaches. More importantly, they are more easily regulated and therefore seen more effectively than chromosomal anomalies [8, 9].

Among the genes most commonly hypermethylated in MM; cell cycle inhibitors P15 and P16, suppressor of cytokine signaling-1 (SOCS-1), E-cadherin promoting cellular adhesion, tumor suppressor genes P73 and Src homology region 2 domain-containing phosphatase-1 (SHP-1) [10]. Adenomatous polyposis coli (APC) also appears as a tumor-suppressor gene that is thought to be effective in the prognosis of MM. APC is a classical tumor-suppressor gene [11] located on the chromosomal band 5q21-q22.13. Although initially associated with colorectal tumors, it has been shown to be associated with other malignancies. The APC protein is a negative regulator of the Wnt (Wingless and Int-1)/beta-catenin pathway. Loss or alteration of APC expression leads to stabilization and nuclear accumulation of beta-catenin. It may, then, result in the activation of downstream genes involved in the initiation of carcinogenesis. It has been shown that methylation of the $\mathrm{CpG}$ island in the APC gene promoter region can lead to suppression of the expression of the APC gene. This disrupts the transmission of the Wnt signaling pathway, leading to the appearance and development of tumors. It has been identified as an effective factor in breast, stomach, esophagus, pancreas and lung cancer [11]. In addition, hypermethylation of the APC gene is closely related to the incidence, development, invasion, and migration of malignant tumors $[11,12]$.

In this study, besides comparing the global DNA and APC 2 gene promotor hypermethylation between patients with $\mathrm{MM}$ and healthy control group, it was aimed to demonstrate the effect of hypermethylation on MM treatment responses, overall survival (OS) and progression-free survival (PFS).

\section{Materials and method}

In this study, 38 patients diagnosed with MM in Gaziantep University Faculty of Medicine Hematology Clinic between January 2016 and January 2020 and 50 without any 
comorbidity in order to create a healthy control group were included. In addition to the demographic data of the patients, such as age and gender; initial Durie-Salmon stages, International Prognostic Index (IPI) scores, Eastern Cooperative Oncology Group (ECOG) scores, laboratory data (hemoglobin, leukocyte, platelet, c-reactive protein (CRP), lactate dehydrogenase (LDH), beta 2 microglobulin, albumin), firstline treatment subtypes, 2-year OS and PFS data, mortality rates and mean follow-up durations (months) were recorded.

In terms of first-line treatments, patients were divided into two groups. Patients in first group underwent autologous stem cell transplantation (ASCT) after obtaining at least partial remission (PR) after 4 cycles of VCD (bortezomib-cyclophosphamide and dexamethasone; bortezomib $1.3 \mathrm{mg} / \mathrm{m}^{2}$ subcutaneous, cyclophosphamide $300 \mathrm{mg} / \mathrm{m}^{2}$ intravenous and dexamethasone $40 \mathrm{mg} /$ week per oral; D1-815-22) and then used LD (lenalidomide-dexamethasone; lenalidomide $10 \mathrm{mg}$ per oral-dexamethasone $40 \mathrm{mg} /$ week per oral) for 24 months. Patients in the second group were not eligible for stem cell transplantation. After 4 cycles of VCD, the least PR response was obtained in this group and maintenance was provided with LD.

Global hypermethylation of the patients before and after first-line treatment (after 4 cycles of standard VCD in all patients) were evaluated using the following method that will be explained in detail. The initial hypermethylation of the patients and the healthy control group were statistically analyzed. In addition, the increase in hypermethylation in the MM group before and after the first series of treatments were analyzed within themselves. Based on the increase or decrease after the treatment in terms of 5-mC values, two separate groups were formed. Post-treatment global DNA and APC 2 gene promoter hypermethylation values as 5-methylated cytosines \% (5-mC \%) were divided into two separate groups as "increasing" and "decreasing" based on pre-treatment values. Both hypermethylation changes and first-line treatment responses of these two groups were compared statistically. APC 2 hypermethylation values were obtained from only 19 patients because only they could be isolated.

The demographic data of the patients, risk scores, MM subtypes (kappa, lambda, light chain), ECOG scores, laboratory parameters, first-line treatment groups and global hypermethylation groups (as increasing and decreasing), OS and PFS were also evaluated statistically.

\section{Blood samples and DNA extraction}

The patients with MM and the control groups' $4 \mathrm{~mL}$ peripheral venous blood samples were collected in EDTA tubes. Genomic DNA was extracted from whole blood by using the Plus Blood Genomic DNA Purification test kit (GeneMark, USA).

\section{Global DNA methylation}

Global genomic DNA methylation was assayed by measurement of 5-mC using the ELISA method as per the manufacturer's protocols (Zymo Research, Germany). The amount of 5-mC was proportional to the optical density (OD) intensity measured at $450 \mathrm{~nm}$. All of the measurements were performed in triplicate within each experiment. For more information please refer to our previously published article [13].

\section{Bisulphite treatment and methylation-specific polymerase chain reaction (MSP-PCR)}

After isolation of DNA, bisulfite modification is an accepted gold standard procedure to detect methylation of DNA. For this analysis, we used the EZ-96 DNA Methylation-Gold kit according to the manufacturer's recommendations (Zymo Research, Germany).

Modified DNA samples were subjected to MSP using APC2 primer pair. One pair of methylated primers were used to amplify methylated regions and one pair of unmethylated primers to amplify unmethylated regions. Bisulphite converted DNA samples were amplified by PCR with Zymo Taq DNA polymerase (Zymo Research) with the primers at the following conditions: $10 \mathrm{~min}$ at $95^{\circ} \mathrm{C}, 40$ cycles $\left(30 \mathrm{~s}\right.$ at $95^{\circ} \mathrm{C}, 40 \mathrm{~s}$ at $69{ }^{\circ} \mathrm{C}$ for methylated primer and $57{ }^{\circ} \mathrm{C}$ for unmethylated primer and $45 \mathrm{~s}$ at $72{ }^{\circ} \mathrm{C}$ ), and $72{ }^{\circ} \mathrm{C}$ for $7 \mathrm{~min}$. The products were separated on $3 \%$ agarose gel and visualized under UV light and taken a photo [14].

\section{Statistical analysis}

SPSS for Windows (version 13.0; SPSS, Chicago, IL) software was used for data analysis. Logistic regression analysis was used to determine the statistical significance of the differences between control groups and patients. The odds ratios (OR) and 95\% confidence intervals were used for this analysis. The X2 test was used to compare the differences between the patient and the control group's global and APC 2 promotor methylation results. Fisher's test was used if necessary. $\mathrm{P}$ values $<0.05$ were considered to indicate statistical significance. The Kaplan-Meier method was used to estimate the survival probabilities and the log-rank test to compare differences. The significance of risk factors was confirmed by applying The Cox stepwise regression analysis. In the multivariate analysis, the stepwise (backward) eliminated variables were used with a significance of less than $10 \%$. 


\section{Results}

A total of 38 patients with a diagnosis of $\mathrm{MM}$ and 50 healthy control persons were included in the study. Fourteen (14) were female $(36.8 \%)$ and 24 were male (63.2\%). When MM subtypes were examined, 5 patients were found to have a lambda light chain (18\%). The OS median value of the patients was 75 months and the PFS median value was 66 months. The mean follow-up period was 19.4 months. Ten (10) patients were exitus (26.3\%) (Table 1).

Twenty-two (57.9\%) of $38 \mathrm{MM}$ patients underwent ASCT after 4 cycles of VCD and received LD maintenance for 2 years. The remaining 16 patients (32.1\%) were followed up with LD until progression, as they were not eligible for ASCT after 4 cycles of VCD (Table 1).
In the statistical analysis performed in terms of clinical findings, there is a significant difference between the patients with MM diagnosis and the healthy control group in terms of the global hypermethylation $(\mathrm{P}=0.001)$. In patients with MM, hypermethylation was significantly higher (Table 1).

When the hypermethylation conditions of the MMdiagnosed patients in pre- and post-treatment states were compared, global hypermethylation in the post-treatment measurements was significantly increased in comparison to the pre-treatment state $(\mathrm{P}=0.012)$. In terms of APC 2 promotor gene-specific hypermethylation, no significant differences were detected between pre-and post-treatment values $(\mathrm{P}=0.368)$ (Table 2).

When the patients' responses to the first-line treatment are examined, there are no meaningful differences observed between the first-line treatment responses and both global DNA hypermethylation and the changes in APC 2 gene

Table 1 Clinical features and treatment regimens of MM patients

\begin{tabular}{|c|c|c|c|c|c|c|}
\hline & & \multicolumn{2}{|l|}{ Multiple myeloma } & \multicolumn{2}{|l|}{ Control } & \multirow[t]{2}{*}{$\mathrm{p}$} \\
\hline & & Median & $\mathrm{n}^{\mathrm{a}}(\%)$ & Median & $\mathrm{n}^{\mathrm{b}}(\%)$ & \\
\hline Age & & $58(41-82)$ & & $54(29-72)$ & & $0.875^{*}$ \\
\hline Gender & Female/male & & $14 / 24(36.8 / 63.2)$ & & $22 / 28(44 / 56)$ & $0.499^{\&}$ \\
\hline 5 -mC value $(\%)$ & & $38.43(4.03-87.84)$ & & $11.04(2.79-18.82)$ & & 0.001* \\
\hline \multirow[t]{2}{*}{ Ig subtypes } & $\kappa / \lambda$ & & $23 / 15(60.5 / 39.5)$ & & & \\
\hline & Light chain & & $5(18)$ & & & \\
\hline \multirow[t]{2}{*}{ Stage (Salmon-Durie) } & II/III & & $18 / 20(16 / 84)$ & & & \\
\hline & $\mathrm{A} / \mathrm{B}$ & & $31 / 7(71 / 29)$ & & & \\
\hline \multirow[t]{2}{*}{ IPI } & I & & $12(31.6)$ & & & \\
\hline & II/III & & $6 / 20(15.8 / 52.6)$ & & & \\
\hline ECOG & $>1$ & & $14(31.6)$ & & & \\
\hline Hemoglobin & $\mathrm{g} / \mathrm{dL}$ & $10.5(7.4-17)$ & & & & \\
\hline Leukocyte & $\mu \mathrm{L}$ & $7125(3680-16,800)$ & & & & \\
\hline Trombocyte & $10^{3} / \mu \mathrm{L}$ & $159(37-680)$ & & & & \\
\hline C-reaktive protein & $\mathrm{mg} / \mathrm{dL}$ & $9(2.1-82)$ & & & & \\
\hline $\mathrm{LDH}$ & IU/L & $380(151-2300)$ & & & & \\
\hline b2-mikroglobulin & $\mathrm{mg} / \mathrm{L}$ & $5.7(1.4-59)$ & & & & \\
\hline Albumin & $\mathrm{g} / \mathrm{L}$ & $3.4(1.9-4.7)$ & & & & \\
\hline \multirow[t]{2}{*}{ Treatment } & VCD, ASCT, LD & & $22(57.9)$ & & & \\
\hline & $\mathrm{VCD} \pm \mathrm{LD}$ & & $16(32.1)$ & & & \\
\hline OS (2-years, \%) & & 75 & & & & \\
\hline PFS (2-years, \%) & & 66 & & & & \\
\hline Mortality & & & $10(26.3)$ & & & \\
\hline Follow up (mean-months) & & $19.4(4.1-34.2)$ & & & & \\
\hline
\end{tabular}

PFS Progression-Free Survival, OS overall survival, IPI International Prognostic Index, ISS International Scoring System, ECOG Eastern Cooperative Oncology Group, $L D H$ lactate dehydrogenase, $C R P$ C-reactive protein, VCD Bortezomib, cyclophosphamide, dexamethasone, ASCT autologous stem cell transplant, $L D$ lenalidomide, dexamethasone, 5- $m C$ 5-methylcytosine

*Median test

${ }^{\&}$ Pearson Chi-square

$\mathrm{n}^{\mathrm{a}}=38$

$\mathrm{n}^{\mathrm{b}}=50$ 
Table 2 Treatment-related methylation change: global and APC 2 methylation

\begin{tabular}{llll}
\hline Multiple myeloma & & & \\
\hline & Pre-treatment & Post-treatment & $\mathrm{P}$ \\
& Median & Median & \\
\hline $\begin{array}{l}\text { 5-mC value (\%) } \\
\mathrm{n}=38\end{array}$ & $38.43(4.03-87.84)$ & $\begin{array}{c}51.29(11.74- \\
96.55)\end{array}$ & $\mathbf{0 . 0 1 2 *}$ \\
APC 2 n $=19$ & & & \\
Unmethylated & 18 & 12 & \\
Partial methylated & 1 & 7 & $0.368^{*}$ \\
\hline
\end{tabular}

5-mC 5-methylcytosine, APC 2 Adenomatous polyposis coli protein 2

$*_{\mathrm{n}}=38 ;{ }^{*}$ median test, ${ }^{\&}$ Fisher's Exact Test

promotor hypermethylation (Global hypermethylation: $\mathrm{P}=0.551$, APC 2 promotor gene: $\mathrm{P}=0.829$ ) (Table 3 ).

The statistical analysis conducted between disease parameters and OS-PFS revealed that both OS and PFS were significantly lower in patients (1) with higher IPI score $(\mathrm{P}=0.013, \mathrm{P}=0.012)$; (2) whose first-line treatments were preferred as VCD $+\mathrm{LD}$ and those who had not been through stem cell transplantation $(\mathrm{P}=0.005, \mathrm{P}=0.003)$; and (3) whose response to the first-line treatment was below partial remission $(\mathrm{PR})(\mathrm{P}=0.001, \mathrm{P}=0.001)$. No significant difference was detected between the global hypermethylation changes in pre-/post-treatment and OS or PFS $(\mathrm{P}=0.367$, $\mathrm{P}=0.414)$ (Table 4).

\section{Discussion}

When the literature is examined in terms of MM and methylation-related outcomes, different results may be encountered. In a study by Larrea et al., the global methylation status and treatment responses of a total of $75 \mathrm{MM}$ patients, treated with bortezomib, were examined. It was observed that patients with a hypermethylated DNA percentage higher than $3.95 \%$ showed better OS $(\mathrm{P}=0.004)$. This study is important in terms of epigenetic changes in plasma cells. It is necessary to highlight the relationship between the increase in DNA methylation percentage and OS. In our study, although there was a significant increase in global DNA methylation in MM patients compared to the healthy control group, an increase in methylation was observed after treatment. Although the statistical relationship between treatment response and methylation has not been revealed at a significant level, this can be defined as an important indicator for prospective studies. DNA hypomethylation, described for solid tumors and chronic lymphocytic leukemia (CLL), plays a role in both gene rearrangements and genomic instability [15]. In this context, treatmentrelated hypermethylation appears as the most emphasized point of our study.

Although studies for MM have not been performed in large patient populations, it is seen that there is a relationship between global DNA hypomethylation and malignant plasma cell clone formation. In addition, it is stated that it is significant for monoclonal gammopathy of undetermined significance (MGUS) to MM transformation. In this study, the initial global hypermethylation was significantly higher in the MM group compared to the healthy controls. It should be emphasized that this is a unique input that has no equivalents in literature in terms of initial global DNA hypermethylation status [16]. Again, in another study conducted on patients with plasma cell leukemia (PCL) transformation, the effect of global hypomethylation on MGUS-MM and PCL transformation was mentioned. However, in this study, we see that there is no analysis comparing before and after treatment.

In the study conducted by Walker et al. [17] in 2011, the relationship between global methylation loss and MGUSMM transition were mentioned. In another study conducted by Kaiser et al. in 2013, the methylation status of global and tumor suppressor genes was discussed in patients with MM. Global hypomethylation and specific gene methylation profiles have been examined; similar to other studies, global hypomethylation has been shown to play a role in the transformation to aggressive plasma cell disorders. Age was associated with lower OS independent of ISS
Table 3 The relationship between methylation status and response to first-line treatment: global and APC 2 methylation

\begin{tabular}{|c|c|c|c|c|c|c|}
\hline & & MM patients & $\begin{array}{l}\text { Response to } \\
\text { first-line treat- } \\
\text { ment }\end{array}$ & OR $\exp (\mathrm{B})$ & $95 \% \mathrm{CI}$ & $\mathrm{P}^{*}$ \\
\hline & & 38 & Response \pm & & & \\
\hline \multirow[t]{2}{*}{5 -mC value $(\%)$} & Increased & 31 & $20 / 11$ & & & \\
\hline & Decreased & 7 & $6 / 1$ & 0.467 & $0.038-5.704$ & 0.551 \\
\hline \multirow[t]{2}{*}{ APC2 } & Unmethylated & 18 & 12 & & & \\
\hline & Partial methylated & 1 & 7 & 1.250 & $0.164-9.538$ & 0.829 \\
\hline
\end{tabular}

$M M$ multiple myeloma, 5- $m C$ 5-methylcytosine, $A P C 2$ adenomatous polyposis coli protein 2

${ }^{\mathrm{a}} \mathrm{n}=38 *$ OR $(95 \% \mathrm{CI})$ was adjusted by age and sex 
Table 4 Univariate analysis (log-rank test) of prognostic factors in 38 patients with MM

\begin{tabular}{|c|c|c|c|c|c|c|}
\hline & & $\mathrm{N}$ & 2-years PFS (\%) & $\begin{array}{l}\text { Log rank } \\
\text { P-value }\end{array}$ & 2 -years OS (\%) & $\begin{array}{l}\text { Log rank } \\
\text { P-value }\end{array}$ \\
\hline & & 38 & 66 & & 75 & \\
\hline Gender & Female/male & $14 / 24$ & $86 / 53$ & 0.177 & $84 / 45$ & 0.251 \\
\hline Age & $<65 / \geq 65$ & $24 / 14$ & $62 / 77$ & 0.733 & $46 / 77$ & 0.695 \\
\hline \multirow[t]{2}{*}{ Stage (Salmon-Durie) } & $\mathrm{II} / \mathrm{III}$ & $20 / 18$ & $78 / 51$ & 0.223 & $76 / 32$ & 0.323 \\
\hline & $\mathrm{A} / \mathrm{B}$ & $31 / 7$ & $66 / 71$ & 0.724 & $57 / 69$ & 0.472 \\
\hline \multirow[t]{3}{*}{ IPI (ISS) } & I & 12 & 91 & & 91 & \\
\hline & II & 6 & 100 & & 100 & \\
\hline & III & 20 & 42 & 0.013 & 25 & 0.012 \\
\hline \multirow[t]{2}{*}{ IPI (ISS) } & $\mathrm{I} / \mathrm{II}$ & 18 & 93 & & 93 & \\
\hline & III & 20 & 42 & 0.006 & 25 & 0.007 \\
\hline \multirow[t]{2}{*}{ Ig subtypes } & $\kappa / \lambda$ & $23 / 15$ & $76 / 57$ & 0.122 & $73 / 47$ & 0.126 \\
\hline & Hafif zincir & 5 & 80 & 0.487 & 80 & 0.432 \\
\hline ECOG & $\leq 1 />1$ & $24 / 14$ & $66 / 69$ & 0.712 & $57 / 69$ & 0.624 \\
\hline Trombocyte $(\times 103 / \mathrm{L})$ & $<150 / \geq 150$ & $6 / 32$ & $40 / 71$ & 0.542 & $42 / 74$ & 0.528 \\
\hline LDH (IU/L) & $<480 / \geq 480$ & $26 / 12$ & $66 / 73$ & 0.885 & $52 / 71$ & 0.912 \\
\hline $\mathrm{CRP}(\mathrm{mg} / \mathrm{L})$ & $<5 / \geq 5$ & $13 / 25$ & $81 / 60$ & 0.195 & $68 / 66$ & 0.135 \\
\hline \multirow[t]{2}{*}{ First-line treatment } & VCD, ASCT, LD & 22 & 80 & & 69 & \\
\hline & $\mathrm{VCD} \pm \mathrm{LD}$ & 16 & 46 & 0.005 & 41 & 0.003 \\
\hline \multirow[t]{2}{*}{ Response status } & CR/VGPR/PR & 25 & 100 & & 100 & \\
\hline & $\mathrm{SD}+\mathrm{PD}$ & 13 & 0 & 0.001 & 0 & 0.001 \\
\hline \multirow[t]{2}{*}{5 -mC value $(\%)$} & Increased & 31 & 73 & & 61 & \\
\hline & Decreased & 7 & 83 & 0.367 & 86 & 0.414 \\
\hline
\end{tabular}

PFS progression-free survival, OS overall survival, IPI International Prognostic Index, ISS international scoring system, ECOG Eastern Cooperative Oncology Group, $L D H$ lactate dehydrogenase, $C R P$ C-reactive protein, $V C D$ bortezomib, cyclophosphamide, dexamethasone, ASCT autologous stem cell transplant, $L D$ lenalidomide, dexamethasone, $C R$ complete response, $V G P R$ very good partial remission, $S D$ stable disease, $P D$ progressive disease, 5- $m C$ 5-methylcytosine

scores and additional cytogenetic abnormalities in terms of hypermethylation of specific tumor suppressor genes such as glutathione peroxidase 3 (GPX3), retinol-binding protein 1 (RBP1), secreted protein acidic and rich in cysteine (SPARC), transforming growth factor beta-induced (TGFBI). When the functions of four different genes are examined, the hypermethylation of "TFBI" that play a role in chemotherapy response, "SPARC" that regulates its relationship with the microenvironment, "RBP1" effective in the retinoic acid signaling pathway and "GPX3", which play a role in the oxidative stress response, are significantly associated with both low OS and low PFS [18].

Traditionally, the "global" loss of methylation of the whole genome and methylation of the associated $\mathrm{CpG}$ islands of the specific genes have been associated with carcinogenesis [19]. APC 2, which is an important tumor suppressor gene, is subject to similar studies. An important study on solid malignancies is a meta-analysis related to bladder cancer in 2018. In a study where a total of 531 controls and 1293 patients from 14 separate studies were included, the relationship between APC promoter region methylation and bladder cancer was evaluated. It has been demonstrated that there is a statistically significant relationship with bladder cancer ( $\mathrm{OR}=17.01, \mathrm{CI}=7.40-39.07)$. At the same time, a significant increase in methylation was observed in correlation with tumor grade [20]. Similarly, in another study from 2018, a significant relationship was shown between esophageal cancer and APC promoter gene methylation [21, 22]. In another meta-analysis of 2018, 2483 patients and 1218 controls from 31 studies were evaluated and the relationship between breast cancer and APC gene methylation was studied. It has been shown that hypermethylation is significantly higher in advanced breast cancer [23].

WNT signal transduction emerges as an important pathway for cell differentiation and growth in hematopoiesis and lymphopoiesis. The WNT signaling pathway is thought to play an important role in the transformation of $\mathrm{MM}$ and plasma cells into a malignant clone [24]. Inhibition of the tumor suppressor, the conserved cylindromatosis (CYLD) involved in the regulation of the WNT pathway in the development of MM; WNT Inhibitory Factor 1 (WIF 1), dickkopf-related protein 1 and 3 (DKK1), (DKK3) and soluble frizzled-related protein 1, 2, 3, 5 (sFRP1, sFRP2, sFRP4, sFRP5') are antagonists of the WNT pathway. In addition 
to promoter hypermethylation, overexpression of the cotranscriptional activator B-cell CLL/lymphoma 9 (BCL9) and $\mathrm{R}$-spondin receptor Leucine-rich repeat-containing G-protein coupled receptor 4 (LGR4) are thought to play a role. The strong binding of both WNT and R-spondins with syndecan-1 "CD-138", which has been identified on the MM cell surface, also contributes to the disease. These epigenetic changes in the WNT 1 signaling pathway can contribute to the proliferation, migration and drug resistance of plasma cells. In addition, it was seen that WNT antagonists are also secreted from plasma cells [25].

In a 2017 study on the WNT signaling pathway, the APC gene in this pathway and hematological malignancies [26], the effect of APC gene expression and hypermethylation in childhood acute lymphoblastic and myeloblastic leukemia (ALL and AML) patients were examined. The APC gene promoter region was found to be hypermethylated in $56 \%$ of patients $(49.2 \%$ B-ALL, $62.5 \%$ T-ALL, $64.1 \%$ AML patients). When APC mRNA levels were examined to evaluate the effect of methylation on gene expression, it was observed that expression was statistically decreased in all ALL patients compared to controls. Aberrant DNA promoter methylation is shown as one of the major factors in hematological malignancies and especially leukemias. Chemotherapy responses or the change that occurs with chemotherapy are also studied in terms of the relationship with the same mutations. In a study conducted with $30 \mathrm{AML}$ patients [14], APC 2 and cytochrome p450 family subfamily B polypeptide (CYP1B1) methylations of bone marrow samples collected before chemotherapy were examined. For APC 2, no change was detected before and after chemotherapy; However, CYP1B promoter hypermethylation was observed to be induced in M3 subtype.

Although the relationship between the MM and WNT signaling pathways has been theoretically explained, the data revealed by clinical studies are not clear. The effects of different tumor suppressor genes on MM and the effect of methylation on the disease response were examined. However, clear data could not be generated for the APC 2 and WNT pathway. Similarly, in another [10] study, hypermethylation of tumor suppressor genes such as $\mathrm{p} 16$, suppressor of cytokine signaling-1 (SOCS-1) p73, E-Caderin and SHP-1 and global hypermethylation in MM has been studied. SOCS-1 hypermethylation was also common in active disease and was significantly frequent in more advanced disease stages. SHP-1 hypermethylation has been associated with low OS. In terms of global DNA hypermethylation, no significant difference was found in terms of active disease or the group in remission. We demonstrated in this study a quite significant post-treatment increase in hypermethylation. In this study, no significant difference was observed in terms of APC 2 promoter gene hypermethylation before or after treatment. Similarly, no statistically significant result was found in treatment response. This is a very important point in terms of literature contribution.

This study also had limitations. The most important point is that the obtained global DNA belongs to all cells, as in most studies. It is not specifically derived from clonal plasma cells. Another important limitation point is that only 19 of the patients included in the study had the APC 2 hypermethylation profile. This can be seen as an obstacle to more sensitive results for APC 2 . The limited patient group and subgroups also prevent possible statistical significance.

In conclusion, this study represents valuable data with the initial global DNA hypermethylation results in the MM patient group and the increase in hypermethylation posttreatment. Although no significant findings were obtained in terms of APC 2 gene promoter hypermethylation due to the limited patient group, it will shed light on future studies.

Acknowledgements We respectfully remember all the colleagues we lost in the COVID-19 fight.

Author contributions All authors contributed to the editing of the manuscript. IS wrote the manuscript and made tables.

Funding No funding was received. None of the authors has disclosures relevant to this manuscript.

Data availability The authors declare that data supporting the findings of this study are available within the referenced articles.

\section{Declarations}

Conflict of interest None to declare.

Ethical approval and consent to participate Ethical committee approval was received (Istanbul University, Faculty of Medicine, approval date and number: 2018/78) and the patients and control subjects gave informed consent before the beginning of the study. The experimental procedures were based on the Declaration of Helsinki and relevant institutional regulations.

Patient consent for publication An informed consent was obtained as written forms from all of our patients to publish.

\section{References}

1. Hillengass J, Usmani S, Rajkumar SV et al (2019) International myeloma working group consensus recommendations on imaging in monoclonal plasma cell disorders [published correction appears in Lancet Oncol. $2019 \mathrm{Jul} ; 20(7): \mathrm{e} 346]$. Lancet Oncol 20(6):302-312. https://doi.org/10.1016/S1470-2045(19)30309-2

2. Siegel RL, Miller KD, Jemal A (2019) Cancer statistics, 2019. CA Cancer J Clin 69(1):7-34. https://doi.org/10.3322/caac.21551

3. Rajkumar SV (2020) Multiple myeloma: 2020 update on diagnosis, risk-stratification and management [published correction appears in Am J Hematol. 2020 Nov;95(11):1444]. Am J Hematol 95(5):548-567. https://doi.org/10.1002/ajh.25791

4. Cavo M, Terpos E, Nanni C et al (2017) Role of 18F-FDG PET/ $\mathrm{CT}$ in the diagnosis and management of multiple myeloma and 
other plasma cell disorders: a consensus statement by the International Myeloma Working Group. Lancet Oncol 18(4):e206-e217. https://doi.org/10.1016/S1470-2045(17)30189-4

5. Herman JG, Baylin SB (2003) Gene silencing in cancer in association with promoter hypermethylation. N Engl J Med 349(21):2042-2054. https://doi.org/10.1056/NEJMra023075

6. Jones PA, Baylin SB (2002) The fundamental role of epigenetic events in cancer. Nat Rev Genet 3(6):415-428. https://doi.org/10. 1038/nrg816

7. Fatemi M, Pao MM, Jeong S, Gal-Yam EN, Egger G, Weisenberger DJ, Jones PA (2005) Footprinting of mammalian promoters: use of a CpG DNA methyltransferase revealing nucleosome positions at a single molecule level. Nucleic Acids Res 33(20):e176. https://doi.org/10.1093/nar/gni180

8. Sandoval J, Mendez-Gonzalez J, Nadal E, Chen G, Carmona FJ, Sayols S, Moran S, Heyn H, Vizoso M, Gomez A, Sanchez-Cespedes M, Assenov Y, Müller F, Bock C, Taron M, Mora J, Muscarella LA, Liloglou T, Davies M, Pollan M, Pajares MJ, Torre W, Montuenga LM, Brambilla E, Field JK, Roz L, Lo Iacono M, Scagliotti GV, Rosell R, Beer DG, Esteller M (2013) A prognostic DNA methylation signature for stage I non-small-cell lung cancer. J Clin Oncol 31(32):4140-4147. https://doi.org/10.1200/JCO. 2012.48.5516

9. Portela A, Esteller M (2010) Epigenetic modifications and human disease. Nat Biotechnol 28(10):1057-1068. https://doi.org/10. 1038/nbt.1685

10. Martínez-Baños D, Sánchez-Hernández B, Jiménez G, BarreraLumbreras G, Barrales-Benítez O (2017) Global methylation and promoter-specific methylation of the P16, SOCS-1, E-cadherin, P73 and SHP-1 genes and their expression in patients with multiple myeloma during active disease and remission. Exp Ther Med 13(5):2442-2450. https://doi.org/10.3892/etm.2017.4274

11. Li BQ, Liu PP, Zhang CH (2017) Correlation between the methylation of APC gene promoter and colon cancer. Oncol Lett 14(2):2315-2319. https://doi.org/10.3892/ol.2017.6455

12. Chen J, Röcken C, Lofton-Day C, Schulz HU, Müller O, Kutzner N, Malfertheiner P, Ebert MP (2005) Molecular analysis of APC promoter methylation and protein expression in colorectal cancer metastasis. Carcinogenesis 26(1):37-43. https://doi.org/10.1093/ carcin/bgh280

13. Sarabi MM, Naghibalhossaini F (2015) Association of DNA methyltransferases expression with global and gene-specific DNA methylation in colorectal cancer cells. Cell Biochem Funct 33(7):427-433. https://doi.org/10.1002/cbf.3126

14. Xia Y, Hong Q, Chen X, Ye H, Fang L, Zhou A, Gao Y, Jiang D, Duan S (2016) APC2 and CYP1B1 methylation changes in the bone marrow of acute myeloid leukemia patients during chemotherapy. Exp Ther Med 12(5):3047-3052. https://doi.org/10.3892/ etm.2016.3719

15. Heuck CJ, Mehta J, Bhagat T, Gundabolu K, Yu Y, Khan S, Chrysofakis G, Schinke C, Tariman J, Vickrey E, Pulliam N, Nischal S, Zhou L, Bhattacharyya S, Meagher R, Hu C, Maqbool S, Suzuki M, Parekh S, Reu F, Steidl U, Greally J, Verma A, Singhal SB (2013) Myeloma is characterized by stage-specific alterations in DNA methylation that occur early during myelomagenesis. J
Immunol 190(6):2966-2975. https://doi.org/10.4049/jimmunol. 1202493

16. Eden A, Gaudet F, Waghmare A, Jaenisch R (2003) Chromosomal instability and tumors promoted by DNA hypomethylation. Science 300(5618):455. https://doi.org/10.1126/science.1083557

17. Walker BA, Wardell CP, Chiecchio L, Smith EM, Boyd KD, Neri A, Davies FE, Ross FM, Morgan GJ (2011) Aberrant global methylation patterns affect the molecular pathogenesis and prognosis of multiple myeloma. Blood 117(2):553-562. https://doi.org/10. 1182/blood-2010-04-279539

18. Kaiser MF, Johnson DC, Wu P, Walker BA, Brioli A, Mirabella F, Wardell CP, Melchor L, Davies FE, Morgan GJ (2013) Global methylation analysis identifies prognostically important epigenetically inactivated tumor suppressor genes in multiple myeloma. Blood 122(2):219-226. https://doi.org/10.1182/ blood-2013-03-487884

19. Schoofs T, Berdel WE, Müller-Tidow C (2014) Origins of aberrant DNA methylation in acute myeloid leukemia. Leukemia 28(1):114. https://doi.org/10.1038/leu.2013.242

20. Han W, Wang Y, Fan J, Wang C (2018) Is APC hypermethylation a diagnostic biomarker for bladder cancer? A meta-analysis. Onco Targets Ther 27(11):8359-8369. https://doi.org/10.2147/ OTT.S177601

21. Zhou D, Tang W, Wang W, Pan X, An HX, Zhang Y (2016) Association between aberrant APC promoter methylation and breast cancer pathogenesis: a meta-analysis of 35 observational studies. PeerJ 14(4):e2203. https://doi.org/10.7717/peerj.2203

22. Wang B, Song H, Jiang H, Fu Y, Ding X, Zhou C (2018) Early diagnostic potential of APC hypermethylation in esophageal cancer. Cancer Manag Res 1(10):181-198. https://doi.org/10.2147/ CMAR.S148677

23. Derksen PW, Tjin E, Meijer HP, Klok MD, MacGillavry HD, van Oers MH, Lokhorst HM, Bloem AC, Clevers H, Nusse R, van der Neut R, Spaargaren M, Pals ST (2004) Illegitimate WNT signaling promotes proliferation of multiple myeloma cells. Proc Natl Acad Sci USA 101(16):6122-6127. https://doi.org/10.1073/pnas. 0305855101

24. Spaan I, Raymakers RA, van de Stolpe A, Peperzak V (2018) Wnt signaling in multiple myeloma: a central player in disease with therapeutic potential. J Hematol Oncol 11(1):67. https://doi.org/ 10.1186/s13045-018-0615-3

25. van Andel H, Kocemba KA, Spaargaren M, Pals ST (2019) Aberrant Wnt signaling in multiple myeloma: molecular mechanisms and targeting options. Leukemia 33(5):1063-1075. https://doi.org/ 10.1038/s41375-019-0404-1

26. Hatırnaz Ng O, Firtına S, Erbilgin Y, Ozbek U, Sayitoglu UUHOD (2017) Aberrant hypermethylation of APC tumor supressor gene in acute leukemia patients. UHOD 10:20. https://doi.org/10.4999/ uhod. 171663

Publisher's Note Springer Nature remains neutral with regard to jurisdictional claims in published maps and institutional affiliations. 